\title{
Evaluation of Trace Metal Contents of Three Local Spices on Accra Markets
}

\author{
Akwasi Akomeah Agyekum ${ }^{1, ~ *, ~ F e l i c i a ~ A k u a m o a ~}{ }^{1}$, Isaac Delali Kottoh², Isaac Kwabena Asare', \\ John Opoku Danquah ${ }^{3}$, Daniel Armah ${ }^{3}$ \\ ${ }^{1}$ Radiological and Medical Research Institute- Ghana Atomic Energy Commission, Legon-Accra, Ghana \\ ${ }^{2}$ Biotechnology and Nuclear Agriculture Research Institute- Ghana Atomic Energy Commission, Legon-Accra, Ghana \\ ${ }^{3}$ Metallic Contaminants Laboratory, Ghana Standards Authority, Accra, Ghana
}

Email address:

agyekumkawasiakomeah@gmail.com (A. A. Agyekum)

To cite this article:

Akwasi Akomeah Agyekum, Felicia Akuamoa, Isaac Delali Kottoh, Isaac Kwabena Asare, John Opoku Danquah, Daniel Armah. Evaluation of Trace Metal Contents of Three Local Spices on Accra Markets. International Journal of Nutrition and Food Sciences.

Vol. 4, No. 6, 2015, pp. 681-687. doi: 10.11648/j.ijnfs.20150406.23

\begin{abstract}
The minerals content of three spices Eugenia caryophyllata, Xylopia aethiopica and Aframomum melegueta from open markets in Accra were determined using Atomic Absorption Spectroscopy (AAS) procedures. Accuracy and precision of the method was evaluated by the certified reference material, NIST SRM 1573a Tomato Leaves. There were differences in essential metal concentrations in the three local spices under the study. The levels of essential trace elements in the three local spices were; $\mathrm{Cu} 0.006-0.012 \mathrm{mg} / \mathrm{kg}$, Zn: 0.011-0.032mg/kg for, Mn: $0.087-0.368 \mathrm{mg} / \mathrm{kg}$, Iron: $0.06-0.116 \mathrm{mg} / \mathrm{kg}, \mathrm{Mg}: 0.032-$ $3.317 \mathrm{mg} / \mathrm{kg}$, Ca: $0.271-5.746 \mathrm{mg} / \mathrm{kg}$, and Na: $0.019-3.889 \mathrm{mg} / \mathrm{kg}$ for sodium. Significant differences were found in the levels of essential trace elements in Eugenia caryophyllata, Xylopia aethiopica and Aframomum melegueta.
\end{abstract}

Keywords: Trace Metal, Atomic Absorption Spectrophotometer, Microwave, Accumulation

\section{Introduction}

Essential trace metals in food are receiving global attention due to importance to mankind. The concentration of trace elements in food is key due to their essential or toxic effects on human life [1]. Iron aids in transport of oxygen in red blood cells and in muscles[2]. Zinc is required for the optimum functioning of many enzymes involved in catalytic functions, maintenance of structural stability, and regulatory functions. Recent findings suggest that copper acts as an antioxidant by protecting the brain and the nervous system [3]. The essential metals can also produce toxic effects depending on the quantity and frequency of consumption.

Spices are used in food regularly to improve colour, aroma, palatability and acceptability of food and consist of rhizomes, barks, leaves, fruits, seeds, and other parts of the plants [4]. Spices combat food borne microorganisms and reduce food poisoning, involve in antioxidant function and antimicrobial activity as well [5]. Work done by [6]indicates that genetic factors, soil and weather conditions, the use of fertilizers, and the state of the plant's maturity at harvest affect the final concentrations of the mineral components in a plant.

In Ghana, spices are used in a lot of diets, yet, there is paucity of nutritional information on indigenous local spices in Ghana. The objective of the study was to evaluate the composition of trace essential elements $(\mathrm{Cu}, \mathrm{Fe}, \mathrm{Mg}, \mathrm{Na}, \mathrm{Ca}$, $\mathrm{Mn}$ and $\mathrm{Zn}$ ) in three indigenous local spices; aimed at contributing to the study of nutritional aspects and building a database on local spices.

\section{Materials and Methods}

\subsection{Apparatus}

A Perkin-Elmer Analyst 700 atomic absorption spectrometer (AAS) with deuterium background corrector was used for the analysis. The required parameters were entered for the operation of the AAS based on the recommendations of the manufacturer. Milestone Ethos D microwave closed system (maximum pressure $1450 \mathrm{psi}$, maximum temperature $300{ }^{\circ} \mathrm{C}$ ) was used. All glasswares were soaked overnight in $10 \%(\mathrm{v} / \mathrm{v})$ nitric acid, followed by washing with $10 \%(\mathrm{v} / \mathrm{v})$ hydrochloric acid. Glasswares were then rinsed with double distilled water and dried before use. 


\subsection{Reagents}

All the reagents and chemicals used were of analytical grade purchased from Merck (Darmstadt, Germany). Concentrated $65 \% \quad \mathrm{HNO}_{3}$ and $30 \% \quad \mathrm{H}_{2} \mathrm{O}_{2}$ were of spectroscopic grades. Double deionised water (Milli-Q Millipore $18.2 \mathrm{M} \Omega / \mathrm{cm}$ conductivity) used for all dilutions was obtained from a Pure Lab Classic machine. Acids; $\mathrm{HNO}_{3}, \mathrm{H}_{2} \mathrm{O}_{2}$, and $\mathrm{HCl}$ were of suprapur quality (E. Merck). All glasswares were soaked in nitric acid solution for 24 hours and rinsed with deionized water before analysis. Analyses were run in triplicates to ascertain the reproducibility of results. Reference standard solutions of copper $(\mathrm{Cu})$, iron $(\mathrm{Fe})$, magnesium $(\mathrm{Mg})$, sodium $(\mathrm{Na})$, calcium $(\mathrm{Ca})$, manganese $(\mathrm{Mn})$ and zinc $(\mathrm{Zn})$ were supplied by Sigma-Aldrich (St Louis, MO,USA).

\subsection{Sampling}

Three spices; Xylopia aethiopica (hwentia), Eugenia caryophyllata (pepre), and Aframomum melegueta (fom wisa) were purchased from major retail markets in the Accra Metropolis and blended to obtain a homogenous unit. The fruit of the spices were used for the analysis.

\subsection{Determination of Metals in Spices by Atomic Absorption Spectrum}

$\mathrm{Cu}, \mathrm{Mg}, \mathrm{Mn}, \mathrm{Fe}, \mathrm{Ca}, \mathrm{Na}$ and $\mathrm{Zn}$ were evaluated by AAS using air/acetylene flame. Elements were analyzed by further diluting the digested spice samples. Dilution was required to bring the concentration within the linear range of the calibration. All the analyses were carried out using flame atomic absorption spectrophotometer at the wavelengths specific for each metal.

\subsection{Microwave Digestion}

One gram of sample was weighed into vessels of the microwave digester (MA 079) with $6 \mathrm{ml}$ of concentrated $\mathrm{HNO}_{3}(65 \%)$ and $2 \mathrm{ml}$ of concentrated $\mathrm{H}_{2} \mathrm{O}_{2} \quad(30 \%)$ respectively. The required parameters were entered for the operation of the microwave digester. The digest were transferred into marked or graduated flask and diluted to the $20 \mathrm{ml}$ mark with deionized water after rinsing the walls of the vessel into it. A blank digest was carried out in the same way (digestion conditions for microwave system were applied as $2 \mathrm{~min}$ for $250 \mathrm{~W}, 2 \mathrm{~min}$ for $0 \mathrm{~W}, 6 \mathrm{~min}$ for $250 \mathrm{~W}, 5 \mathrm{~min}$ for $400 \mathrm{~W}, 8 \mathrm{~min}$ for $550 \mathrm{~W}$, vent: $8 \mathrm{~min}$, respectively). In order to validate the microwave digestion method for accuracy and precision, NIST SRM 1573a Tomato Leaves certified reference material were analysed for corresponding elements.

Table 1. Concentration $(\mathrm{mg} / \mathrm{kg})$ of metals in spices.

\begin{tabular}{|c|c|c|c|c|c|c|c|}
\hline Spices & Mn & Zn & Mg & $\mathbf{N a}$ & $\mathbf{C a}$ & $\mathrm{Cu}$ & $\mathbf{F e}$ \\
\hline E.caryophyllata & $0.368 \pm 0.001^{\mathrm{a}}$ & $0.011 \pm 0.009^{\mathrm{a}}$ & $3.317 \pm 0.003^{\mathrm{a}}$ & $3.889 \pm 0.008^{\mathrm{a}}$ & $5.746 \pm 0.009^{\mathrm{a}}$ & $0.006 \pm 0.003^{\mathrm{a}}$ & $0.116 \pm 0.005^{\mathrm{a}}$ \\
\hline A. melegueta & $0.150 \pm 0.001^{\mathrm{b}}$ & $0.032 \pm 0.009^{b}$ & $0.032 \pm 0.003^{b}$ & $0.019 \pm 0.008^{b}$ & $0.271 \pm 0.009^{b}$ & $0.006 \pm 0.003^{\mathrm{a}}$ & $0.078 \pm 0.005^{b}$ \\
\hline X. aethiopica & $0.087 \pm 0.001^{\mathrm{b}}$ & $0.015 \pm 0.009^{\mathrm{a}}$ & $1.931 \pm 0.003^{\mathrm{c}}$ & $4.191 \pm 0.008^{\mathrm{a}}$ & $4.191 \pm 0.009^{\mathrm{a}}$ & $0.012 \pm 0.003^{b}$ & $0.06 \pm 0.005^{\mathrm{b}}$ \\
\hline
\end{tabular}

Table 2. Working conditions for the analysis of trace elements by atomic absorption spectrophotometer.

\begin{tabular}{lllllll}
\hline Metals & $\begin{array}{l}\text { Wavelength } \\
\text { (nm) }\end{array}$ & $\begin{array}{l}\text { Silt } \\
\text { width } \\
\text { (nm) }\end{array}$ & $\begin{array}{l}\text { Lamp } \\
\text { current } \\
\mathbf{( \% )}\end{array}$ & Gas & Support \\
\hline $\mathrm{Fe}$ & 248.3 & 0.2 & 75 & Acetylene & Air \\
$\mathrm{Na}$ & 589.0 & 0.2 & 75 & Acetylene & Air \\
$\mathrm{Mn}$ & 279.5 & 0.2 & 75 & Acetylene & Air \\
$\mathrm{Mg}$ & 285.2 & 0.5 & 75 & Acetylene & Air \\
$\mathrm{Zn}$ & 213.9 & 0.2 & 75 & Acetylene & Air \\
$\mathrm{Ca}$ & 422.7 & 0.5 & 100 & Acetylene & Air \\
$\mathrm{Cu}$ & 324.8 & 0.5 & 75 & Acetylene & Air \\
\hline
\end{tabular}

\subsection{Statistical Analysis}

Data obtained were analysed for significant differences and the mean separation was done using Microsoft excel.

\section{Results and Discussion}

Minerals are inorganic elements that remain behind in the ash when food is incinerated. Minerals are usually divided in two groups; macro-minerals and micro-minerals (or trace elements), and also classified as either essential or nonessential, depending on whether or not they are required for human nutrition and have metabolic roles in the body [7].As reported by [8], some minerals are components of antioxidants and enzymes: superoxide dismutase depends on $\mathrm{Mn}, \mathrm{Cu}$ and $\mathrm{Zn}$; catalase depends on $\mathrm{Fe}$, and glutathione peroxidase on Se. Magnesium is also present in mitochondria and other enzymes important in energy transfer [9].

The concentrations of essential trace metals in the three local spices under the study were found to be in the range of $0.087-0.368 \mathrm{mg} / \mathrm{kg}$ for manganese, $0.011-0.032 \mathrm{mg} / \mathrm{kg}$ for zinc, $0.032-3.317 \mathrm{mg} / \mathrm{kg}$ for magnesium, $0.019-3.889$ $\mathrm{mg} / \mathrm{kg}$ for sodium, and $0.06-0.116 \mathrm{mg} / \mathrm{kg}$ for iron.

Calcium was found in all three local spice samples with concentrations ranging from $0.271 \mathrm{mg} / \mathrm{kg}$ to $5.746 \mathrm{mg} / \mathrm{kg}$. The highest concentration of $5.746 \mathrm{mg} / \mathrm{kg}$ as dry wt was recorded by Eugenia caryophyllata (pepre). Calcium has a lot of benefit; it is good for blood clotting and also for good health and bone development. [10]contend that calcium deficiency leads to hypochromic anaemia, leucopenia and osteoporosis in children as corroborated by [11]. Recent findings also suggest that calcium is essential for good health but very high intake can cause adverse health problems such as liver and kidney damage [12]. Calcium levels in vegetables have been reported in the range of $0.07-7.30 \mu \mathrm{g} / \mathrm{g}$ [13], 4.9-9.4 $\mu \mathrm{g} / \mathrm{g}$ [14], 0.3- $1.4 \mu \mathrm{g} / \mathrm{g}$ [15], 3.7-16.2 $\mu \mathrm{g} / \mathrm{g}$ [16], 7.6-9.6 $\mu \mathrm{g} / \mathrm{g}$ [17], 0.2-8.5 $\mu \mathrm{g} / \mathrm{g}$ [18], and $0.8-5.3 \mu \mathrm{g} / \mathrm{g}$ [19]. There were significant differences between Pepre and 
fom wisa as well as between Hwentia and fom wisa but no significant difference between pepre and hwentia.

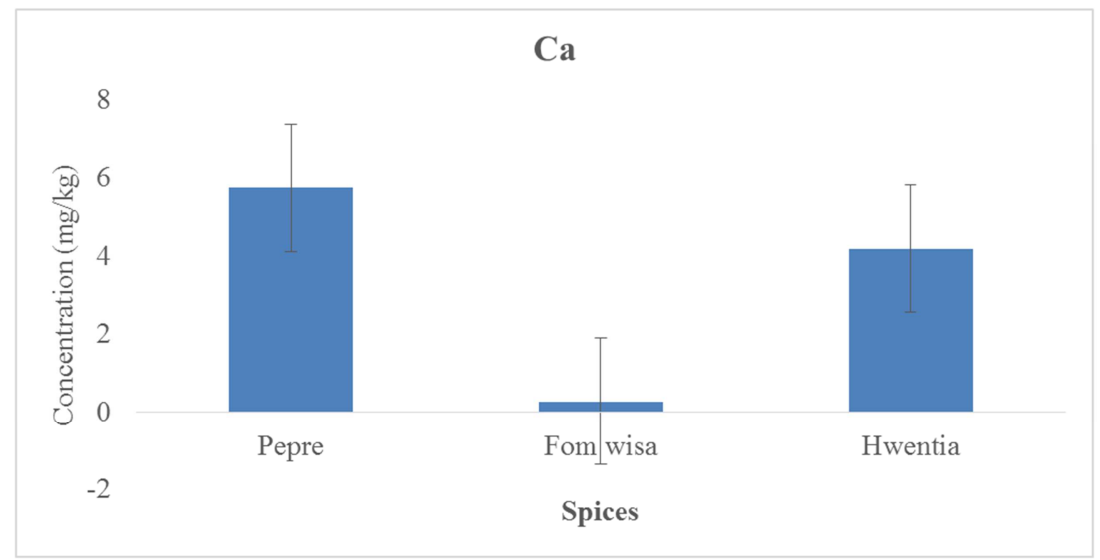

Fig. 1. Distribution of calcium in Eugenia caryophyllata (pepre), Aframomum melegueta (fom wisa) and Xylopia aethiopica (hwentia).

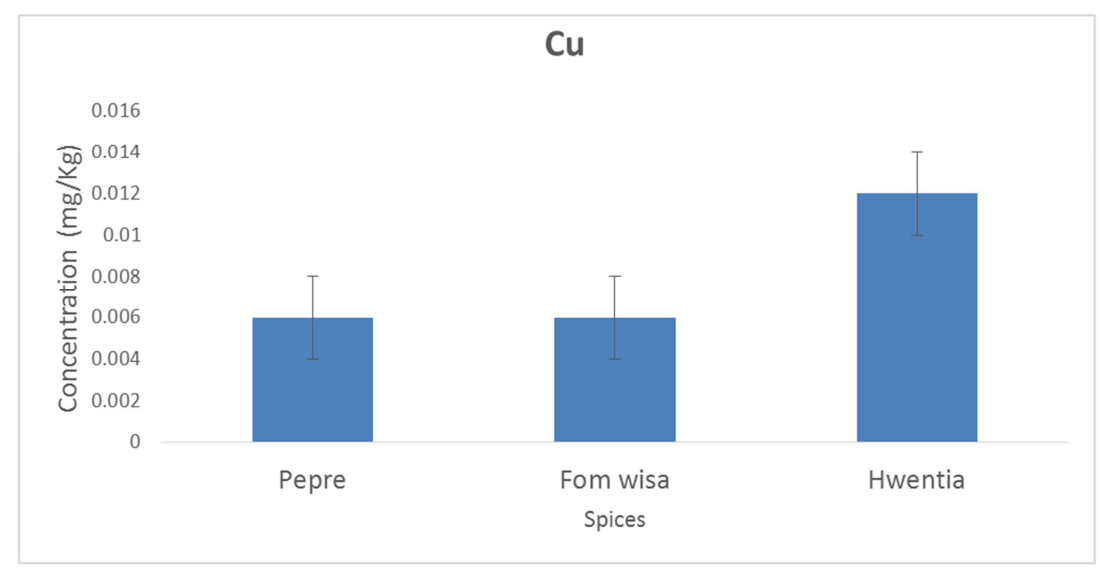

Fig. 2. Distribution of copper in Eugenia caryophyllata (pepre), Aframomum melegueta (fom wisa) and Xylopia aethiopica (hwentia).

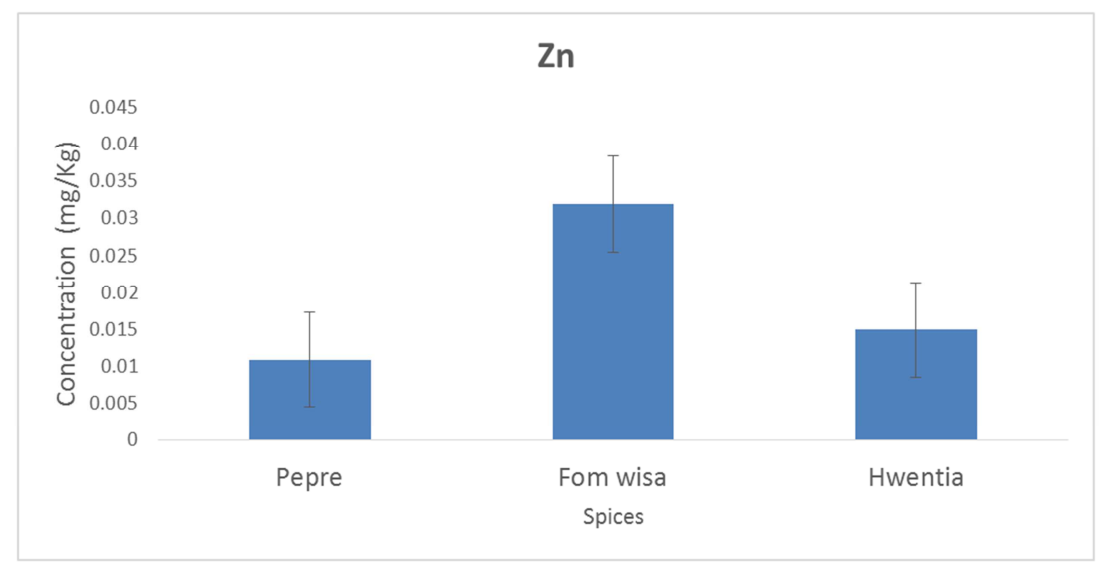

Fig. 3. Distribution of Zinc in Eugenia caryophyllata (pepre), Aframomum melegueta (fom wisa) and Xylopia aethiopica (hwentia).

Copper was present in all the selected spices studied but in minimal quantities. Hwentia had the highest value of 0.012 $\mathrm{mg} / \mathrm{kg}$ as dry weight whiles pepre and fom wisa had 0.006 $\mathrm{mg} / \mathrm{kg}$ as dry weight. There were no significant difference $(\mathrm{p} \geq 0.05)$ in copper concentrations between Eugenia caryophyllata (pepre) and Aframomum melegueta (fom wisa) but with hwentia, there were significant difference $(p \leq 0.05)$. Copper is required for normal growth of infants and bone strength. It also aids in the maturation of erythrocytes and leukocytes which and acts as a defence mechanism for the host and also helps in brain development. Deficiency may be associated with a variety of symptoms related to reduce activity of enzymes containing copper. It can also lead to loss of skin pigmentation. Excessive intake has an irritating effect on the gastrointestinal tract. [20] reported the range of copper to be between 3 to $11 \mu \mathrm{g} / \mathrm{g}$ with the highest level in nutmeg and black pepper. [21]reported concentrations far below the toxic limit of $30 \mathrm{mg} / \mathrm{kg}$. $\mathrm{Cu}$ is known to be both vital and 
toxic for many biological systems and may enter the food materials from soil through mineralization by crops, food processing or environmental contamination, as in the application of agricultural inputs, such as copper-based pesticides which are in common use in farms in some countries [22].

Zinc was found in all three local spice samples and with concentrations ranging from $0.011 \mathrm{mg} / \mathrm{kg}$ to $0.032 \mathrm{mg} / \mathrm{kg}$. The highest $\mathrm{Zn}$ concentration was recorded by Aframomum melegueta (fom wisa) $(0.032 \mathrm{mg} / \mathrm{kg}$ as dry wt.). There were no significant differences between hwentia and pepre but with fom wisa, there was. [1] reported that zinc is one of the most important trace metals for normal growth and development of humans and helps with strong immune system. Deficiency of zinc can result from inadequate dietary intake, impaired absorption, excessive excretion or inherited defects in zinc metabolism. A study conducted by [23] indicated that zinc has a tendency to get bio-accumulated in the fatty tissues of aquatic organisms, including fish and is known to affect reproductive physiology in fishes. [24]reported that chronic exposure to $\mathrm{Cu}$ and $\mathrm{Zn}$ is associated with Parkinson's disease and these elements might act alone or together over time to induce the disease. Zinc deficiency may lead to lesion on the skin and also affect bone metabolism and gonadal function [25]. $\mathrm{Zn}$ has no unpaired electrons when in the state $\mathrm{Zn}^{2+}$ preventing its participation in redox reactions. Nonetheless, $\mathrm{Zn}$ has been recognized to act as an antioxidant by replacing metals that are active in catalyzing free radical reactions, such as Fe [26]; [27]. The FAO/WHO has set a limit for trace metal intakes based on body weight. For an average adult ( $60 \mathrm{~kg}$ body weight), the provisional tolerable daily intake (PTDI) for iron, copper and zinc are 48,3 and $60 \mathrm{mg}$, respectively [28].

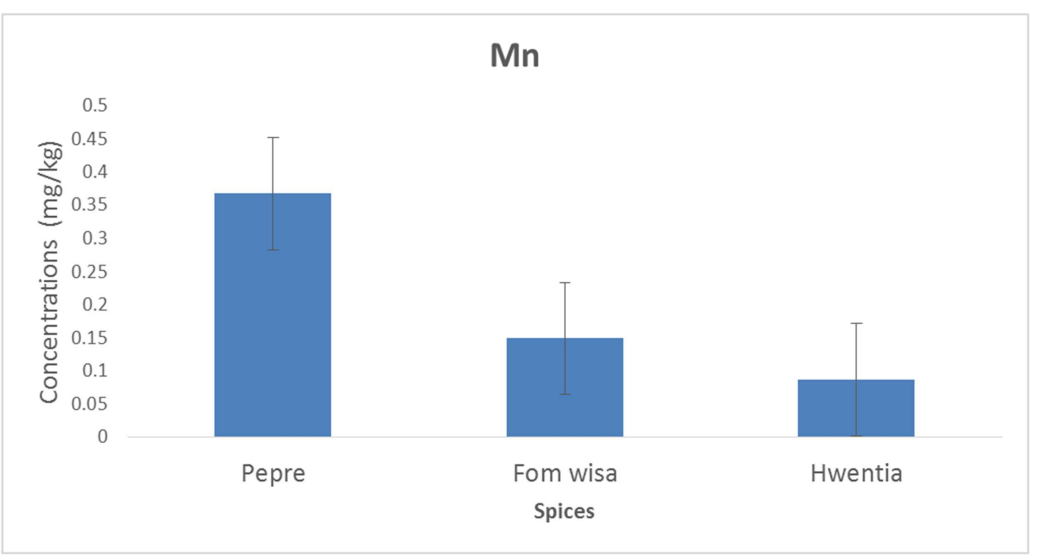

Fig. 4. Distribution of Manganese in Eugenia caryophyllata (pepre), Aframomum melegueta (fom wisa) and Xylopia aethiopica (hwentia).

Mn is linked with bone development, and with amino acid, lipid, and carbohydrate metabolism. Manganese is one of the essential trace elements since it is necessary for the development of foetus and necessary as a co-factor for several enzymes [29]. Deficiency can result in poor bone formation and skeletal defects, reduced fertility and birth defects. It can also delay growth in children. High intake of Manganese that is above $10 \mathrm{mg} / \mathrm{kg}$ which is the recommended dose by [30] is regarded as a neurotoxic substance.

Manganese levels may also be affected by food processing. The levels of manganese in the three local spices were from $0.087 \mathrm{mg} / \mathrm{kg}$ for Xylopia aethiopica (hwentia) to $0.368 \mathrm{mg} / \mathrm{kg}$ in Eugenia caryophyllata (pepre) samples. There were significant differences between pepre and the other two spices. Manganese in food may also be affected by processing.

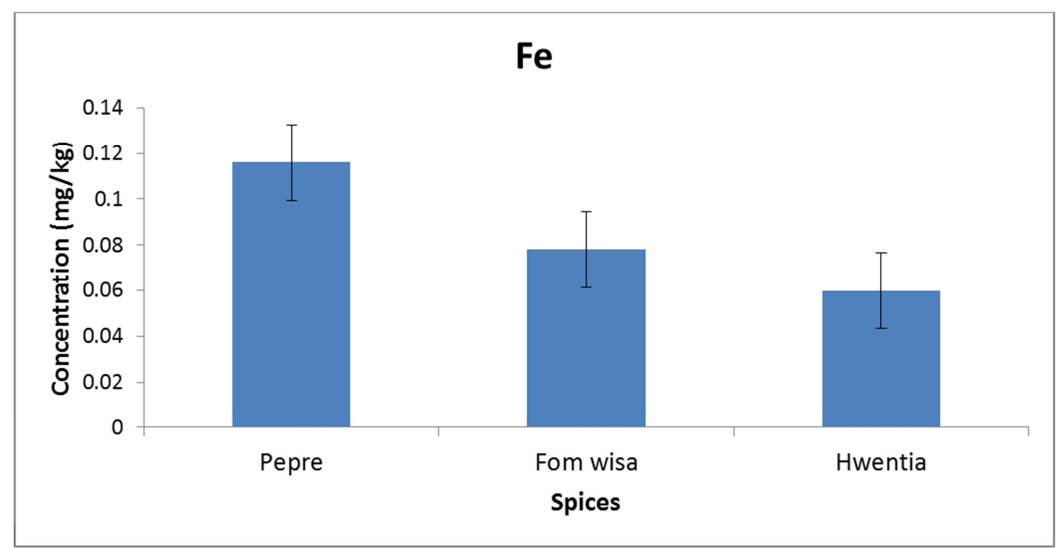

Fig. 5. Distribution of Iron in Eugenia caryophyllata (pepre), Aframomum melegueta (fom wisa) and Xylopia aethiopica (hwentia). 
Adequate amount of iron in a diet is very essential for decreasing the incidence of anaemia. Iron dearth occurs when the demand for iron is high, e.g., in growth, high menstrual loss, and pregnancy, and the intake is quantitatively inadequate or contains elements that render the iron unavailable for absorption [22]. Averagely, the iron content in the three spices ranged from $0.06 \mathrm{mg} / \mathrm{kg}$ in Xylopia aethiopica (hwentia) to $0.116 \mathrm{mg} / \mathrm{kg}$ in Eugenia caryophyllata (pepre) samples. There were no significant difference in $\mathrm{Fe}$ concentrations recorded by fom wisa and hwentia but with pepre, there was a significant difference ( $\mathrm{p} \leq$ $0.05)$.

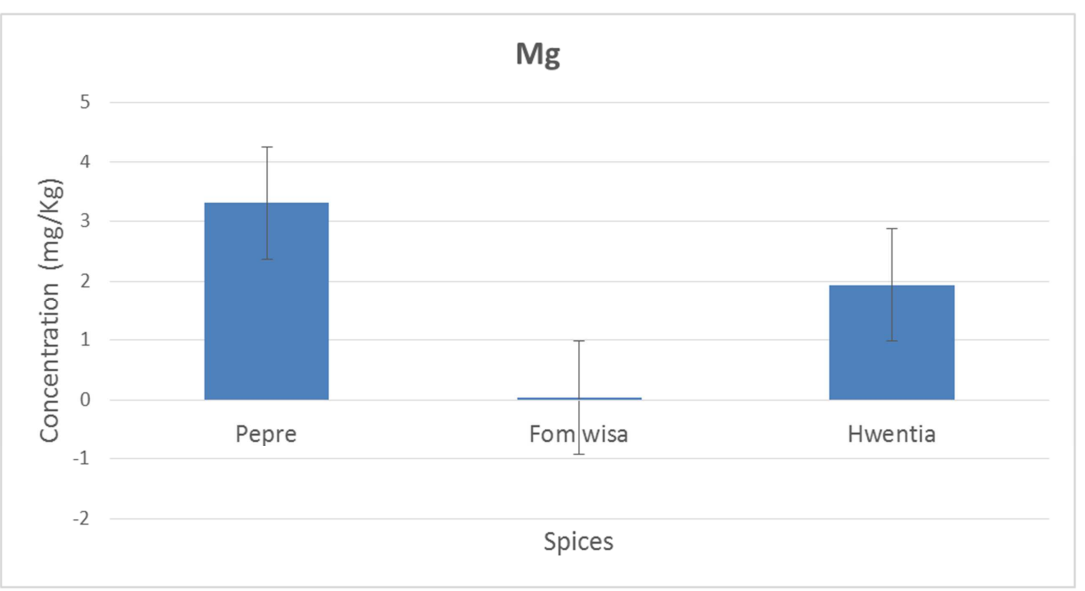

Fig. 6. Distribution of Magnesium in Eugenia caryophyllata (pepre), Aframomum melegueta (fom wisa) and Xylopia aethiopica (hwentia).

Magnesium is known to provide strength; aids enzyme function and helps nerve and heart function. According to [31] magnesium deficiency leads to weakness, muscle pain, poor heart function, insomnia and nausea. [9]states that magnesium present in mitochondria and other enzymes is important in energy transfer. Magnesium content ranged from
$1.135 \mathrm{mg} / \mathrm{kg}$ in Aframomum melegueta (fom wisa) to 3.317 $\mathrm{mg} / \mathrm{kg}$ in Eugenia caryophyllata (pepre) samples. There were no significant difference between pepre and hwentia but significant differences existed between pepre and fom wisa as well as between hwentia and fom wisa.

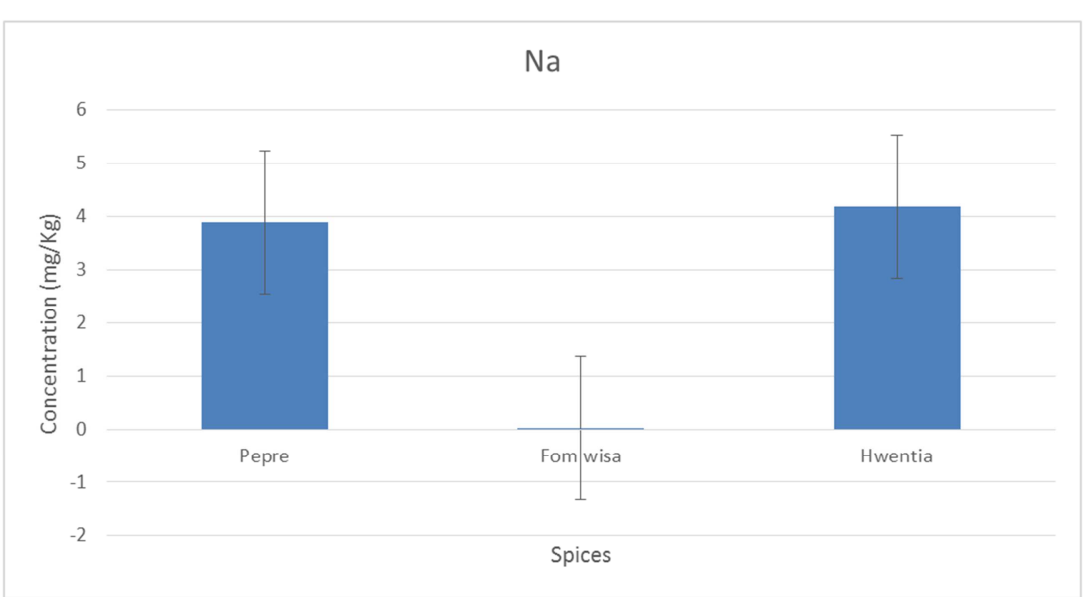

Fig. 7. Distribution of Sodium in Eugenia caryophyllata (pepre), Aframomum melegueta (fom wisa) and Xylopia aethiopica (hwentia).

Sodium in a diet helps to regulate the fluid balance of the body both within and outside the cells. Deficiency may lead to low blood pressure and high intake may lead to dehydration, consistent high intake may lead to hypertension. Sodium content ranged from $0.019 \mathrm{mg} / \mathrm{kg}$ in Aframomum melegueta (fom wisa) to $3.889 \mathrm{mg} / \mathrm{kg}$ in Eugenia caryophyllata (pepre) samples. There were no significant difference in $\mathrm{Na}$ concentrations $(\mathrm{p} \geq 0.05)$ between pepre and hwentia but with fom wisa, there were significant differences $(\mathrm{p} \leq 0.05)$. The mineral concentrations varied among different spices which may be attributed to differential absorption capacity of test spices for different metals which is consistent with the findings of [32]. The variations in the concentrations of the minerals in the spices observed during the present study may be ascribed to the physical and chemical nature of the soil at the production sites, absorption capacities of heavy metals by vegetables, atmospheric deposition of heavy metals, which may be influenced by innumerable environmental factors such as temperature, moisture and wind velocity, and the nature of the vegetables, i.e. leafy, root, fruit, exposed surface area, hairy or smoothness of the exposed parts [33]. Eugenia caryophyllata, A. melegueta and 
$X$. aethiopica can be considered as alternative source of $\mathrm{Mn}$, $\mathrm{Zn}, \mathrm{Mg}$, $\mathrm{Na}$ and $\mathrm{Ca}$. Based on the results, the spices on Ghanaian markets are safe for human consumption.

\section{Conclusion}

The study was to evaluate the essential trace metals composition of three local spices on Ghanaian markets. There were significant differences in essential metal concentrations in the three local spices studied. The outcome of this study has provided vital information on essential mineral contents of spices on Ghanaian markets and ultimately indicates their nutritive potential.

The trace mineral concentrations $(\mathrm{Cu}, \mathrm{Fe}, \mathrm{Mg}, \mathrm{Na}, \mathrm{Ca}, \mathrm{Mn}$ and $\mathrm{Zn}$ ) in the spices analysed were all within the prescribed limits set by various authorities, except in few cases. As a result, the spices on Ghanaian markets are safe for human consumption. It is therefore recommended that regular monitoring of trace metals in spices and other food commodities be performed in order to prevent undue buildup of these metals in the human food chain.

\section{Acknowledgement}

We are grateful to the staff of the Metallic Contaminants Laboratory of the Ghana Standards Authority for their support.

\section{References}

[1] Ozturk, E. Atsan, E. Polat, T. Kara, K. (2011) Variation in heavy metal concentrations of potato (Solanum tuberosum L.) cultivars. Journal of Animal and Plant Sciences, 21(2): 235239.

[2] Vallee, B.L., Auld, D.S. 1990. Zinc coordination, function, and structure of zinc enzymes and other proteins. Biochemistry 29, 5647-59.

[3] Wardlaw, G. M. (2003). Contemporary Nutrition, Issues and Insight. 5th edition. New York: The McGraw Hill Companies. pp 317-325.

[4] Sattar, A., Wahid, M., Durrani, S.K. (1989). Concentration of selected heavy metals in spices, dry fruits and plant nuts. Plant Foods for Human Nutrition 39:279-286.

[5] Gupta, K.K., Bhattacharjee, S., Kar, S., Chakrabarty,S., Thakur, P., Bhattacharyya, G., Srivastava, S.C. 2003. Mineral compositions of eight common Sspices", Communications in Soil Science and Plant Analysis. Vol.34. Nos 5\&6. Pp 681693.

[6] Piscopo, A., Romeo, F. V., Petrovicova, B., Poiana, M. 2010. Effect of the harvest time on kernel quality of several almond varieties (Prunus dulcis (Mill.) D.A.Webb). Scientia Horticulturae, 125, 41-46.

[7] Tiburski, J.H., Rosenthal A., Deliza R., Godoy, R.L.D., Pacheco, S. (2011). Nutritional properties of yellow mombin (Spondias mombin L.) pulp. Food Research International, 44:2326-2331.
[8] Evans, P., and Halliwell, B. (2001). Micronutrients: Oxidant/antioxidant status. British Journal of Nutrition, 85, S67-S74.

[9] Barros, H.R.d.M., Ferreira, T.A.P.d.C., Genovese. 2012. Antioxidant capacity and mineral content of pulp and peel from commercial cultivars of citrus from Brazil. Food Chemistry134, 1892-1898.

[10] Kanumakala, S., Boneh, A., Zacharin, M., 2002. Pamidronate treatment improves bone mineral density in children with Menkes disease. J. Inherit. Metab. Dis. 25, 391-398.

[11] Dilek B., Kurtulus, Y.B., Yurtsever, S. 2013. Comparison of extraction induced by emulsion breaking, ultrasonic extraction and wet digestion procedures for determination of metals in edible oil samples in Turkey using ICP-OES, Food Chemistry.

[12] Ikem, A., Egiebor, N.O. 2005. Assessment of trace elements in canned fishes (mackerel, tuna, salmon, sardines and herrings) marketed in Georgia and Alabama (United States of America). Journal of Food Composition and Analysis 18, 771-787.

[13] Onianwa, P.C., Adeyemo, A.O., Idowu, O.E., Ogabiela, E.E. 2001. Copper and zinc contents of Nigerian foods and estimates of the adult dietary intakes. Food Chemistry 72, 8995 .

[14] Bahemuka, T.E., Mubofu, E.B. 1999. Heavy metals in edible green vegetables grown along the sites of the Sinza and Msimbazi rivers in Dar es Salaam, Tanzania. Food Chemistry 66, 63-66.

[15] Sanchez-Castillo, C.P., Dewey, P.J.S., Aguirre, A., Lara, J.S., Vaca, R., de la Barra, P.L. (1998). The mineral content of Mexican fruits and vegetables. Journal of Food Composition and Analysis 11,340-356.

[16] Gebeloglu, N., Camcicetin, S., Ece, A., Sari, H., Mendil, D., Tuzen, M. 2004. Determination of trace metals in soil, bean and tomato samples collected from agricultural areas near the motorway in Tokat, Turkey. Asian Journal of Chemistry 16, $1500-1504$

[17] Tuzen, M. 2003. Determination of heavy metals in fish samples of the middle Black Sea (Turkey) by graphite furnace atomic absorption spectrometry. Food Chemistry. 27, 521-526.

[18] Ferreira, K.S., Gomes, J.C., Chaves, J.B.P. 2005. Copper content of commonly consumed food in Brazil. Food Chemistry 92, 29-32.

[19] Divrikli, U., Saracoglu, S., Soylak, M., Elci, L. 2003. Determination of trace heavy metal contents of green vegetable samples from Kayseri- Turkey by flame atomic absorption spectrometry. Fresenius Environmental Bulletin 12(9), 1123-1125.

[20] Seddigi, Z. S., G. A. Kandhro, F. Shah, E. Danish, and M. Soylak. 2013 .Assessment of metal contents in spices and herbs from Saudi Arabia", Toxicology and Industrial Health.

[21] Sivaperumal, P., Sankar, T.V., Nair, P.G.V. (2007). Heavy metal concentrations in fish, shellfish and fish products from internal markets of India vis-a-vis international standards. Food Chemistry 102,612-620.

[22] Tuzen, M. 2009. Toxic and essential trace elemental contents in fish species from the Black Sea, Turkey. Food and Chemical Toxicology. 47, 1785-1790. 
[23] Ghosh, B.B., Mukhopandhyay, M.K., Bagchi, M.M. 1985. Proc. National Seminar on Pollution Control and Environmental Management pp. 194-199.

[24] Rahman, M.S. 2012. Study on heavy metals levels and its risk assessment in some edible fishes from Bangshi River, Savar, Dhaka, Bangladesh", Food Chemistry, 1015.

[25] Nishi, Y. 1996. Zinc and growth. Journal of the American College of Nutrition 14(4), 340-344.

[26] Oteiza, P.I., Mackenzie, G.G., Verstraeten, S.V., 2004. Metals in neurodegeneration: involvement of oxidants and oxidantsensitive transcription factors. Mol. Aspects Med. 25, 103115 .

[27] Zago, M.P., Oteiza, P.I., 2001. The antioxidant properties of zinc: interactions with iron and antioxidants. Free Radic. Biol. Med. 31, 266-274.

[28] FAO/WHO Expert Committee on Food Additives 1999. Summary and conclusions. In: 53rd Meeting, Rome, June 1$10,1999$.
[29] Iqbal, Javed, and Munir H. Shah. 2014. Study of seasonal variations and health risk assessment of heavy metals in Cyprinus carpio from Rawal Lake, Pakistan", Environmental Monitoring and Assessment, 2014.

[30] World Health Organization 1994. Quality directive of potable water $2^{\text {nd }}$ ed., pp. 197.

[31] Ladaniya, M. S., 2008. Citrus fruit: Biology, technology and evaluation. San Diego, CA: Academic Press (Elsevier).

[32] Zurera G, Moreno R, Salmeron J, Pozo R. (1989). Heavy metal uptake from greenhouse border soils for edible vegetables. J. Sci. Food Agric. 49:307-314.

[33] Sharma, R.K., Agrawal, M., Marshall, F.M., 2009. Heavy metal in vegetables collected from production and market sites of tropical urban area of India. Food Chem. Toxicol. 47, 583591. 